\title{
高分解能誘導結合プラズマ質量分析法による高純度ジルコニア中 微量不純物の定量
}

\author{
中 根 清 ${ }^{\circledR 1}$
}

\author{
Determination of trace impurities in high-purity zirconium oxide by \\ high-resolution inductively coupled plasma mass spectrometry
}

\begin{abstract}
Kiyoshi NAKANE $^{1}$
${ }^{1}$ National Institute of Advanced Industrial Science and Technology (AIST), Ceramics Research Institute, 2266 - 98, Anagahora, Shimoshidami, Moriyana, Nagoya-shi, Aichi 463 - 8560
\end{abstract}

(Received 14 March 2003, Accepted 11 December 2003)

\begin{abstract}
Using high resolution inductively coupled plasma mass spectrometry (HR-ICP-MS), trace impurities in high-purity zirconium oxide powder samples were determined. A $0.5 \mathrm{~g}$ zirconium oxide sample was dissolved with $5 \mathrm{ml}$ of sulfuric acid $(1+1)$ in a PTFE pressure vessel at $230^{\circ} \mathrm{C}$ for $40 \mathrm{~h}$. Most of the spectral interferences were avoided by using a high-resolution spectrometer. The matrix effects of $\mathrm{Zr}$ were investigated. Since the matrix effects of a high Zr concentration on the peaks of the internal standard were similar to those on almost all of the analyte elements, except for Hf, the internal-standard method was employed for quantitative analysis. Indium was used for the internal standard element. The analytical values, except for Hf obtained by the internal-standard method, approximately agreed with those obtained by the standard addition method. The analytical values of the Hf obtained by ICP-AES approximately agreed with those obtained by the standard addition method. The detection limits in the solid samples were in the range of $0.01 \sim 9 \mu \mathrm{g} \mathrm{g}^{-1}$. The determinations for $\mathrm{Na}, \mathrm{Mg}, \mathrm{Al}, \mathrm{Ca}, \mathrm{Ti}, \mathrm{V}, \mathrm{Cr}$, $\mathrm{Mn}, \mathrm{Fe}, \mathrm{Ni}, \mathrm{Sr}, \mathrm{Cs}$, La, Ce, Hf, $\mathrm{Pb}$ and $\mathrm{Bi}$ in three kinds of commercially available high-purity zirconium oxide powders are presented.
\end{abstract}

Keywords : high-resolution inductively coupled plasma mass spectrometry; high-purity zirconium oxide ; matrix effects ; internal standard method.

\section{1 緒言}

ジルコニアは, 固体電解質, 酸素センサー, 耐熱材料な どに用いられている。 また，構造材料としての用途を拡大 する動きも近年盛んになってきている。ジルコニアの高機 能・高性能化のために, 原料粉末の高純度化が指向されて おり，それに伴って微量不純物の定量が重要となってい る. ジルコニア中金属不純物の定量は, 一般的に誘導結合 プラズマ原子発光分析法（ICP-AES）によってなされてい る ${ }^{1) \sim 3)}$. しかしながら ICP-AES を用いた場合, 測定できる

独立行政法人産業技術総合研究所セラミックス研究部門：4638560 愛知県名古屋市守山区下志段味穴ヶ洞 2266-98
不純物濃度はほとんどの元素で $\mu \mathrm{g} \mathrm{g}^{-1}$ レベルにとどまっ ており, 高純度ジルコニア中微量不純物の定量には不十分 である，ICP-AES では，特に重元素では高感度検出が難し いため, 分析は難しい妾.

誘導結合プラズマ質量分析法（ICP-MS）は $\mu \mathrm{g} \mathrm{g}^{-1}$ 以下 レベルの微量成分の分析を行える超高感度な分析法とし て，近年著しい発展を遂げている は四重極質量分析計（QMS）を備えた ICP-QMS が多い. ICP-QMS の分解能は単位質量程度であるため, スペクト ル干渉が問題となる場合がある ${ }^{6) 71}$. ジルコニア中の不純 物の多くは質量数 80 以下であるが，ジルコニアを硫酸を 用いて分解して得た試料溶液の質量数 80 以下の ICP-MS 
スペクトルにおいては，目的とする不純物元素のイオンピ ークにプラズマガス $(\mathrm{Ar})$, 大気中のガス $\left(\mathrm{CO}_{2}, \mathrm{~N}_{2}, \mathrm{O}_{2}\right)$, 水 $\left(\mathrm{H}_{2} \mathrm{O}\right)$, 酸 $\left(\mathrm{H}_{2} \mathrm{SO}_{4}\right)$ やマトリックス元素 $(\mathrm{Zr})$ から 成る様々な種類の原子イオンや分子イオンピークが重な る.ICP-QMS では, これらの妨害イオンピークと目的元 素のイオンピークを分離することは困難である。この困難 を克服するため, 本研究では磁場と電場セクターから成る 二重収束型質量分析装置を備えた高分解能誘導結合プラズ マ質量分析装置（HR-ICP-MS）を用いた ${ }^{8) ~ 10)}$ ・この装置 の分解能 $(R)$ は最高約 10000 であるため, ほとんどの妨 害イオンピークから分析元素イオンピークを分離すること ができる.

ICP-MS 測定では，あらかじめ試料を溶液にする必要が ある. ジルコニアは硫酸又はフッ化水素酸+塩酸で分解で きるが1)，フッ化水素酸＋塩酸による分解法を用いると試 料溶液が装置の石英製トーチを侵すので, 本研究では硫酸 で分解した。硫酸溶液を ICP-MS に導入するとコーン材料 を腐食するし，硫黄を含む分子イオンを生成して ${ }^{32} \mathrm{~S}^{16} \mathrm{O}^{+}$ イオンが ${ }^{48} \mathrm{Ti}^{+}$イオンの測定を妨害するために, ICP-MS 測定においては通常避けられる. 本研究では高濃度の硫酸 によるコーンの腐食を避け ${ }^{11)}$, また高濃度のマトリックス 溶液を導入したときに生じるコーンの目詰まりやプラズマ の点灯時の放電を防止するため, 高倍率の希釈を行って測 定した。

ICP-MS におけるマトリックス効果は ICP-AES に比べて 重大であるため, 多くの研究において詳しく検討されてい る. ICP-QMS については多数の報告がなされている が12) 17), HR-ICP-MS については報告例は少ない ${ }^{18)}$. 特に ジルコニアについてマトリックス効果は報告されていな w.

また，ICP-MS によるジルコニア粉末の分析については， 幾つかの報告がなされている19) 21). いずれの報告におい ても良好な分析值と低い検出限界值が得られているが, ICP-QMS では ArO の干渉を分離できないため, $\mathrm{Fe}$ の分析 は難しい ${ }^{19)}$. 試料分解に硫酸アンモニウムによる融解法を 用いたり ${ }^{20)}$, 試料分解が硝酸 + フッ化水素酸 + 過酸化水素

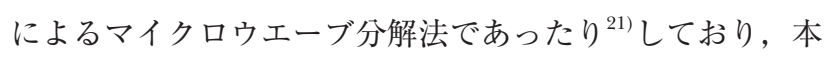
報告が目的とする硫酸を使用した加圧酸分解法による HRICP-MS を用いた微量成分の定量についてはなされていな w.

本報告では HR-ICP-MS を用いて，Zr によるマトリック ス効果を検討し, 幾つかの市販の高純度ジルコニア粉末中 の微量不純物を定量した.

$$
2 \text { 実験 }
$$

\section{$\mathbf{2} \cdot \mathbf{1}$ 装置, 試料}

用いた HR-ICP-MS 装置は，日本電子製 JMS-PLASMAX1
型である．この装置では，質量分解能は約 $10000 （ 10 \%$ 谷）まで連続的に変化させることができる．試料溶液の導 入には Gilson 製 Minipuls-3 型ペリスタルチックポンプを 用いた. Hf 定量結果の比較のため, 日本ジャーレル・ア ッシュ製 ICAP-1000S 型 ICP-AES 装置を使用した。

測定元素の検量線用標準溶液の調製においては， Na， $\mathrm{Mg}, \mathrm{Al}, \mathrm{Ca}, \mathrm{Ti}, \mathrm{V}, \mathrm{Cr}, \mathrm{Mn}, \mathrm{Fe}, \mathrm{Ni}, \mathrm{Sr}, \mathrm{Pb}$ につい ては Merck 製 Titrisol を, 内標準元素 In と測定元素の Cs, Bi については和光純薬製原子吸光分析用金属標準液 (1000 $\left.\mathrm{mg} \mathrm{l}^{-1}\right)$ を, La, Ceについては Spex 製 XSTC-1 $\left(10 \mathrm{mg} \mathrm{l}^{-1}\right)$ をそれぞれ用いた。測定元素の Hf の標準溶 液（1000 $\mathrm{mg} \mathrm{l}^{-1} ）$ については酸化ハフニウム（Spex 製 HF20）を次のように調製して得た。酸化ハフニウム $0.1179 \mathrm{~g}$ をフッ化水素酸 $(1+1) 2.5 \mathrm{ml}$ によりテフロン加 圧分解容器中で分解した。 この分解液に硫酸 $1 \mathrm{ml}$ を添加 し, 加熱してフッ化水素酸を除いた後純水で $100 \mathrm{ml}$ に希 釈した。

水は蒸留水を Millipore 製 Milli-QSP 型超純水製造装置 で精製して用いた.ジルコニアを分解するための硫酸は多 摩化学工業製 Tamapure AA-100を用いた.

試料分解には, 三愛科学製 HU-25 型テフロン加圧分解 容器を用いた。 ピペット，メスフラスコなどの器具類はす ベてプラスチック製のものを用いた。

\section{$2 \cdot 2$ 試料調製}

市販の高純度ジルコニア粉末 3 種類（A， B， C）を分析 に供した。試料分解法は既報に準じ1), ジルコニア試料 $0.5 \mathrm{~g}$ をテフロン分解容器に取り, $5 \mathrm{ml}$ の硫酸 $(1+1)$ を 加えて $230^{\circ} \mathrm{C}$ で 16 時間加熱した. しかし 16 時間加熱し ても完全に分解できなかったため，40 時間加熱して完全 に分解した。冷却後, 純水にて $100 \mathrm{ml}$ に希釈した。ICPAES ではそのまま，HR-ICP-MS ではそれを更に 25 倍に希 釈して測定溶液とした。したがって，HR-ICP-MS 測定溶 液中の $\mathrm{Zr}$ と硫酸濃度は, それぞれ約 $150 \mathrm{mg} \mathrm{l}^{-1}$ （ジルコ ニアとして $200 \mathrm{mg} \mathrm{l}^{-1}$ ) と $0.18 \%$ である.

\section{3 結果及び考察}

\section{$3 \cdot 1$ 定性分析}

まず，実験に用いた 3 種のジルコニア試料の定性分析 を行った. 試料 A, B, C について質量数 1 から 280 まで, 分解能約 500 と約 5000 で測定した。検出された 15 元素 ( $\mathrm{Na}, \mathrm{Mg}, \mathrm{Al}, \mathrm{V}, \mathrm{Cr}, \mathrm{Mn}, \mathrm{Fe}, \mathrm{Ni}, \mathrm{Sr}, \mathrm{Cs}, \mathrm{La}, \mathrm{Ce}$, $\mathrm{Hf}, \mathrm{Pb}, \mathrm{Bi}$ ) に Ca と $\mathrm{Ti}$ を加えた 17 元素を測定対象元素 として選定した.

\section{$3 \cdot 2$ 質量分解能}

高分解能の測定ではスリット幅を狭めるため, 透過する 
Table 1 Some spectral interferents in sample solution of high purity zirconium oxide

\begin{tabular}{|c|c|c|c|}
\hline Isotopes & Isotopic abundance, $\%$ & Interferents & Mass resolution required \\
\hline${ }^{40} \mathrm{Ca}^{+}$ & 96.9 & ${ }^{40} \mathrm{Ar}^{+}$ & 192000 \\
\hline${ }^{44} \mathrm{Ca}^{+}$ & 2.1 & ${ }^{28} \mathrm{Si}^{16} \mathrm{O}^{+},{ }^{12} \mathrm{C}^{16} \mathrm{O}_{2}{ }^{+}$ & 2690,1280 \\
\hline${ }^{46} \mathrm{Ti}^{+}$ & 8.0 & ${ }^{92} \mathrm{Zr}^{2+}$ & 406000 \\
\hline${ }^{47} \mathrm{Ti}^{+}$ & 7.3 & ${ }^{94} \mathrm{Zr}^{2+}$ & 33700 \\
\hline${ }^{48} \mathrm{Ti}^{+}$ & 73.8 & ${ }^{96} \mathrm{Zr}^{2+},{ }^{32} \mathrm{~S}^{16} \mathrm{O}^{+}$ & 7750,2520 \\
\hline${ }^{49} \mathrm{Ti}^{+}$ & 5.5 & ${ }^{32} \mathrm{~S}^{16} \mathrm{O}^{1} \mathrm{H}^{+}$ & 1820 \\
\hline${ }^{50} \mathrm{Ti}^{+}$ & 5.4 & ${ }^{34} \mathrm{~S}^{16} \mathrm{O}^{+}$ & 2780 \\
\hline${ }^{52} \mathrm{Cr}^{+}$ & 83.8 & ${ }^{40} \mathrm{Ar}^{12} \mathrm{C}^{+}$ & 2380 \\
\hline${ }^{55} \mathrm{Mn}^{+}$ & 100 & ${ }^{94} \mathrm{Zr}^{16} \mathrm{O}^{2+},{ }^{40} \mathrm{Ar}^{14} \mathrm{~N}^{1} \mathrm{H}^{+}$ & 4370,1560 \\
\hline${ }^{56} \mathrm{Fe}^{+}$ & 91.7 & ${ }^{96} \mathrm{Zr}^{16} \mathrm{O}^{2+},{ }^{40} \mathrm{Ar}^{16} \mathrm{O}^{+}$ & 3360,2500 \\
\hline
\end{tabular}

イオンの数が減少して感度が低下する，それゆえ，微量不 純物を測定するには分析元素イオンピークから干渉する分 子イオンピークを分離するのに十分で，かつ高すぎない分 解能で測定する必要がある。分析元素イオンピークは, マ トリックス元素 $(\mathrm{H}, \mathrm{C}, \mathrm{N}, \mathrm{O}, \mathrm{S}, \mathrm{Ar}, \mathrm{Zr})$ の分子イオ ンピークや原子イオンピークなどに重ならない同位体か, 重なったとしても分離可能で存在度が最大の同位体とし た. Table 1 は分析イオンピークから干渉する分子イオン ピークを分離するのに必要な分解能を示したものである. $\mathrm{Ca}$ については, 最高分解能で測定しても ${ }^{40} \mathrm{Ca}$ (同位体存 在度 $96.9 \%$ ） ${ }^{40} \mathrm{Ar}$ のピークから分離できないため, 同 位体存在度が約 $2 \%$ のもの $\left({ }^{44} \mathrm{Ca}\right)$ を測定した。 Tiにつ いては Table 1 に示すように, ${ }^{46} \mathrm{Ti}^{+},{ }^{47} \mathrm{Ti}^{+},{ }^{48} \mathrm{Ti}^{+}$がそれ ぞれ ${ }^{92} \mathrm{Zr}^{2+},{ }^{94} \mathrm{Zr}^{2+},{ }^{96} \mathrm{Zr}^{2+}$ と重なり， ${ }^{46} \mathrm{Ti},{ }^{47} \mathrm{Ti}$ は分解能 10000 にしても分離できない. ${ }^{48} \mathrm{Ti}$ は計算上分解能 8000 で ${ }^{96} \mathrm{Zr}^{2+}$ から分離できるが, ${ }^{96} \mathrm{Zr}^{2+}$ ピークのすそ野の影響 のため測定に用いることは難しい. そこで, 分子イオンと 分離できる ${ }^{49} \mathrm{Ti}$ を選んだ。以上の検討の結果, 測定した 同位体は ${ }^{23} \mathrm{Na},{ }^{24} \mathrm{Mg},{ }^{27} \mathrm{Al},{ }^{44} \mathrm{Ca},{ }^{49} \mathrm{Ti},{ }^{51} \mathrm{~V},{ }^{52} \mathrm{Cr},{ }^{55} \mathrm{Mn}$, ${ }^{56} \mathrm{Fe},{ }^{58} \mathrm{Ni},{ }^{88} \mathrm{Sr},{ }^{133} \mathrm{Cs},{ }^{139} \mathrm{La},{ }^{140} \mathrm{Ce},{ }^{180} \mathrm{Hf},{ }^{208} \mathrm{~Pb},{ }^{209} \mathrm{Bi}$ である。

干渉イオンによる重なりのない分析イオンピーク（Na, $\mathrm{Mg}, \mathrm{Cs}, \mathrm{Hf}, \mathrm{Pb}, \mathrm{Bi})$ は低分解能 $(R=500)$ で測定し た。 ${ }^{180} \mathrm{Hf}^{+}$は ${ }^{90} \mathrm{Zr}_{2}{ }^{+}$と重なることが考えられるが，定性分 析モード（質量数 0 から 280 まで高速スキャン）ととも に, 高分解能 $(R=5000)$ の定量分析モード（質量数 180 付近の低速スキャン) で積分を重ねても $\mathrm{Zr}_{2}{ }^{+}$ピークは認 められなかったため, $\mathrm{Zr}_{2}{ }^{+}$ピークはほとんど無視できる と判断し, 分解能 500 で測定した。

低分解能で測定した上記 6 元素以外の元素について, 必要な分解能の検討を行った. Fig. 1 は約 $150 \mathrm{mg} \mathrm{l}^{-1}$ の $\mathrm{Zr}$ 溶液に Mn $1 \mu \mathrm{g} \mathrm{l}^{-1}$ 添加して測定した結果を図示し

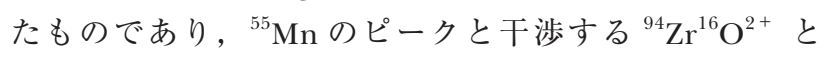
${ }^{40} \mathrm{Ar}^{14} \mathrm{~N}^{1} \mathrm{H}^{+}$のピークの分解能約 5000 (A) と分解能約 10000 (B) でのスペクトルを示した. ${ }^{55} \mathrm{Mn}^{+}$のピークは 分解能約 5000 では完全に分離されていないが, Fig. 1(B)
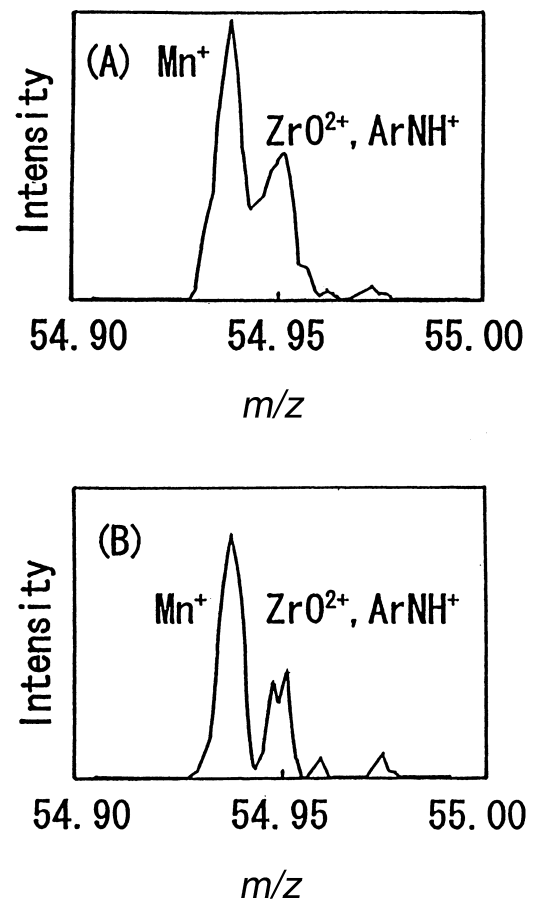

Fig. 1 Mass spectra of ${ }^{55} \mathrm{Mn}^{+}$of $1 \mu \mathrm{g} \mathrm{l}{ }^{-1},{ }^{94} \mathrm{Zr}^{16} \mathrm{O}^{2+}$ and ${ }^{40} \mathrm{Ar}^{14} \mathrm{~N}^{1} \mathrm{H}^{+}$

A: Mass resolution was about 5000; B: Mass resolution was about 10000 .

に示すように, 分解能約 10000 で測定すれば十分である. ${ }^{56} \mathrm{Fe}$ も分子イオン $\left(\mathrm{ArO}^{+}\right)$の干渉を受けるが, 同様に分 解能 10000 で測定すると分離できた。そこでこれら 2 元 素は分解能約 10000 で測定した。 ${ }^{27} \mathrm{Al},{ }^{44} \mathrm{Ca},{ }^{49} \mathrm{Ti},{ }^{51} \mathrm{~V}$, ${ }^{52} \mathrm{Cr},{ }^{88} \mathrm{Sr}$ の各ピークは分解能約 5000 で測定した。測定 分解能を Table 2 にまとめて示した.

\section{$3 \cdot 3$ 装置条件}

それぞれのイオンピーク強度として, ピーク面積を用い た。検出系に実際に記録されるイオンピーク強度は，幾つ かの測定条件に依存している。これらの条件のうち，エア ロゾルキャリヤーガス流量とサンプリング深さはピーク強 度に及ぼす影響が大きい ${ }^{22)}$. 分析対象元素のうち ${ }^{23} \mathrm{Na}$, 
Table 2 Mass resolution, detection limits and blank test

\begin{tabular}{crcc}
\hline Isotopes & Resolution & $\begin{array}{c}\text { Detection limits }{ }^{\mathrm{a})} / \\
\mu \mathrm{g} \mathrm{g}^{-1}\end{array}$ & $\begin{array}{c}\text { Blank test/ } \\
\mu \mathrm{g} \mathrm{g}^{-1}\end{array}$ \\
\hline${ }^{23} \mathrm{Na}$ & 500 & 0.1 & $<0.1$ \\
${ }^{24} \mathrm{Mg}$ & 500 & 0.06 & $<0.06$ \\
${ }^{27} \mathrm{Al}$ & 5000 & 0.1 & $<0.1$ \\
${ }^{44} \mathrm{Ca}$ & 5000 & 9 & $<9$ \\
${ }^{49} \mathrm{Ti}$ & 5000 & 1 & $<1$ \\
${ }^{51} \mathrm{~V}$ & 5000 & 0.06 & $<0.06$ \\
${ }^{52} \mathrm{Cr}$ & 5000 & 0.2 & $<0.2$ \\
${ }^{55} \mathrm{Mn}$ & 10000 & 0.08 & $<0.08$ \\
${ }^{56} \mathrm{Fe}$ & 10000 & 0.8 & $<.0$ \\
${ }^{58} \mathrm{Ni}$ & 5000 & 0.3 & $<0.3$ \\
${ }^{88} \mathrm{Sr}$ & 5000 & 0.5 & $<0.5$ \\
${ }^{133} \mathrm{Cs}$ & 500 & 0.01 & $<0.01$ \\
${ }^{139} \mathrm{La}$ & 10000 & 0.4 & $<0.4$ \\
${ }^{140} \mathrm{Ce}$ & 10000 & 0.8 & $<0.8$ \\
${ }^{180} \mathrm{Hf}$ & 500 & $0.2(5)$ & $<0.2$ \\
${ }^{208} \mathrm{~Pb}$ & 500 & 0.01 & 0.04 \\
${ }^{209} \mathrm{Bi}$ & 500 & 0.1 & $<0.1$ \\
\hline
\end{tabular}

a) Value in parenthesis was obtained by ICP-AES.

Table 3 Instrumental conditions for the HR-ICP-MS

$\begin{array}{ll}\text { ICP conditions } & \\ \text { RF power } & 1200 \mathrm{~W} \\ \text { Radiofrequency } & 40.68 \mathrm{MHz} \\ \text { Gas flow rate } & \\ \quad \text { Coolant gas flow } & 14.01 / \mathrm{min} \\ \quad \begin{array}{l}\text { Auxiliary gas flow } \\ \text { Aerosol carrier gas flow }\end{array} & 0.801 / \mathrm{min} \\ \text { Sampling cone } & \text { copper } \\ \text { Skimmer cone } & \text { copper } \\ \text { Sampling depth } & 8.9 \mathrm{~mm} \text { from load coil } \\ \text { Sampling uptake rate } & 0.17 \mathrm{ml} / \mathrm{min} \\ \text { Mass analyser conditions } & 5 \mathrm{kV} \\ \text { Acceleration voltage } & 500 / 5000 / 10000 \\ \text { Mass resolution }(10 \% \text { valley) } & \\ \text { Sweep conditions } & 6000 \mathrm{ppm}{ }^{\mathrm{a})} / 2000 \mathrm{ppm} / \\ \quad \text { Sweep range } & 2000 \mathrm{ppm} \\ \text { Switcing rate } & 1000 \mathrm{~ms} \\ \text { Sweep number } & 10 \\ \text { Main slit } & 1400 \mu \mathrm{m} / 140 \mu \mathrm{m} / 70 \mu \mathrm{m} \\ \text { alpha-slit } & 9.0 \mathrm{~mm} / 1.5 \mathrm{~mm} / 0.75 \mathrm{~mm} \\ \text { collector slit } & 300 \mu \mathrm{m} / 30 \mu \mathrm{m} / 15 \mu \mathrm{m} \\ \text { Ion lens setting } & \mathrm{Maximize}\end{array}$

a) Part per million

\footnotetext{
${ }^{24} \mathrm{Mg},{ }^{27} \mathrm{Al}, \quad{ }^{208} \mathrm{~Pb}$ についてキャリヤーガス流量の最適值を

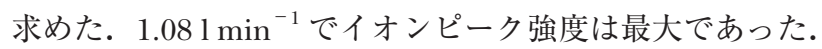
次にサンプリング深さの最適值を測定したところ，8.9 $\mathrm{mm}$ であった。測定に用いた装置条件を Table 3 にまとめ て示した。

\section{$3 \cdot 4$ マトリックス効果}

石塚らは先に ICP-AES 測定において, 硫酸並びに Zr マ トリックスが不純物の発光強度に影響を及ぼすことを報告
}

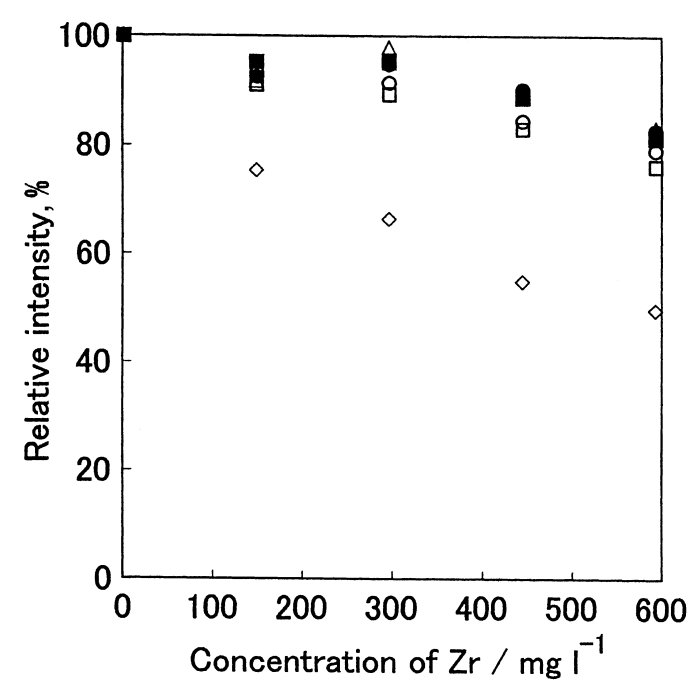

Fig. 2 Relative intensity of several analyte elements and internal standard element as a function of zirconium concentration for: $\mathrm{Na}, \boldsymbol{M g}, \boldsymbol{\Delta} \mathrm{Al}, \bigcirc \mathrm{In}, \square$ Cs, $\diamond \mathrm{Hf}, \triangle \mathrm{Pb}$

$10 \mu \mathrm{gl}^{-1}$ each solution was used.

している1). ICP-QMS についての Z $\mathrm{Zr}$ によるマトリックス 効果については報告されていないが，HR-ICP-MS 測定に おいても，これらのマトリックスが分析元素イオンピーク 強度に及ぼす影響を検討する必要がある。硫酸濃度 $1 \%$ の各元素の信号強度は， $0.02 \%$ のときのそれに比べて約 $40 \%$ 程度減少した。硫酸によるマトリックス効果は，標 準溶液並びに測定溶液の硫酸濃度を一定に保つことによ り，無視することができた。

次いで $\mathrm{Zr}$ 濃度による $\mathrm{Na}, \mathrm{Mg}, \mathrm{Al}, \mathrm{Cs}, \mathrm{Hf}, \mathrm{Pb}$ の各イ オンピーク強度に対する依存性を検討した。 Zr 濃度を 0 から約 $600 \mathrm{mg} \mathrm{l}^{-1}$ まで変えて分析元素 6 元素（各 $10 \mu \mathrm{g}$ $\left.1^{-1}\right)$ のイオンピーク強度を測定した。各点は 3 回ずつ測 定し，平均をとった值である。各溶液の硫酸濃度は約 $0.74 \%$ とした。 $\mathrm{Zr}$ マトリックスとして試料 A を用い，試 料中の不純物による影響については補正した。

Fig. 2 には上記 6 元素の Zr によるマトリックス効果に ついて検討した結果を示す．図中のそれぞれの点は Zr が $0 \mathrm{mg} \mathrm{l} \mathrm{l}^{-1}$ のもののイオンピーク強度に対する比で示した. Hf を除く 5 元素のイオンピーク強度比は $\mathrm{Zr}$ 濃度が増加す るに従って徐々に下がったが，Hf は他に比べて下がり方 が大きかった. $\mathrm{Zr}$ 濃度約 $600 \mathrm{mg} \mathrm{l}^{-1}$ の際の他の 5 元素の 信号強度は， $\mathrm{Zr}$ 溶液 $0 \mathrm{mg} \mathrm{l}^{-1}$ のときのそれに比べて約 $20 \%$ 程度減少したが，Hf は約 50\% 減少した.Hf が異な る原因については分からない。

市販のファインセラミックス原料や焼結体を対象にした ICP-AES の場合では，測定試料よりも高純度のジルコニア を用いて，測定溶液とマトリックスを一致させた検量線用 
Table 4 Analytical results for commercially available high purity zirconium oxide samples

\begin{tabular}{cccc}
\hline Elements & Sample $^{\mathrm{a})} / \mu \mathrm{g} \mathrm{g}^{-1}$ & Sample $^{\mathrm{a})} / \mu \mathrm{g} \mathrm{g}^{-1}$ & Sample C $^{\mathrm{a})} / \mu \mathrm{g} \mathrm{g}^{-1}$ \\
\hline $\mathrm{Na}$ & $1.3 \pm 0.1(1.1)$ & $0.6 \pm 0.1(0.6)$ & $0.7 \pm 0.3(0.8)$ \\
$\mathrm{Mg}$ & $1.01 \pm 0.02(0.89)$ & $0.28 \pm 0.03(0.21)$ & $0.19 \pm 0.06(0.06)$ \\
$\mathrm{Al}$ & $2.1 \pm 0.2(2.4)$ & $1.9 \pm 0.1(2.2)$ & $1.1 \pm 0.3(1.6)$ \\
$\mathrm{Ca}$ & $<9(<9)$ & $<9(<9)$ & $<9(<9)$ \\
$\mathrm{Ti}$ & $<1(<1)$ & $<1(<1)$ & $3.40 \pm 0.55(3.29)$ \\
$\mathrm{V}$ & $<0.06(<0.06)$ & $<0.06(<0.06)$ & $0.3 \pm 0.3(0.3)$ \\
$\mathrm{Cr}$ & $0.3 \pm 0.3(0.5)$ & $0.3 \pm 0.2(<0.2)$ & $<0.08(<0.08)$ \\
$\mathrm{Mn}$ & $<0.08(<0.08)$ & $<0.08(<0.08)$ & $<0.8(<0.8)$ \\
$\mathrm{Fe}$ & $<0.8(<0.8)$ & $<0.3(<0.8)$ & $<0.3(<0.3)$ \\
$\mathrm{Ni}$ & $0.8 \pm 0.2(0.9)$ & $0.5 \pm 0.1(0.5)$ & $<0.5(<0.5)$ \\
$\mathrm{Sr}$ & $<0.5(<0.5)$ & $0.02 \pm 0.01(<0.01)$ & $<0.4(0.5)$ \\
$\mathrm{Cs}$ & $0.05 \pm 0.05(<0.01)$ & $0.6 \pm 0.5(<0.4)$ & $0.8 \pm 0.6(1.3)$ \\
$\mathrm{La}$ & $<0.4(<0.4)$ & $<0.8(0.8)$ & $10.9 \pm 0.2(24.1)<27>$ \\
$\mathrm{Ce}$ & $<0.8(<0.8)$ & $16.3 \pm 0.9(31.5)<30>$ & $0.09 \pm 0.02(0.06)$ \\
$\mathrm{Hf}$ & $5.2 \pm 0.1(16.7)<16>$ & $0.13 \pm 0.01(0.16)$ & $3.3 \pm 0.5(3.8)$ \\
$\mathrm{Pb}$ & $10.4 \pm 2.1(12.6)$ & $0.3 \pm 0.3(0.3)$ & \\
$\mathrm{Bi}$ & $0.3 \pm 0.1(0.2)$ & & \\
\hline
\end{tabular}

a) Mean of five measurements \pm standard deviation; Values in parentheses ( ) were obtained by standard addition method, values in parentheses $<>$ were obtained by ICP-AES.

標準溶液を用いることにより，これらのマトリックスの影 響を除去することが可能である1 ${ }^{1}$. しかしながら，本研究 で対象とする試料は高純度ジルコニアであり，それょり更 に 2 けた程度高純度な Zr マトリックスの入手は現状では 不可能である。また，検量線作成に使用可能なジルコニア 標準物質も存在しない。そこで測定する元素とマトリック スの影響が一致する内標準元素を用いてマトリックスの影 響を補正することについて検討した。ICP-QMS 測定にお いては内標準元素として Sc, Y, In, Rh，Biがよく使わ れる ${ }^{23) 24)}$. そのうち $\mathrm{Bi}$ は分析元素であり, ${ }^{45} \mathrm{Sc}^{+},{ }^{89} \mathrm{Y}^{+}$, ${ }^{103} \mathrm{Rh}^{+}$はそれぞれ ${ }^{90} \mathrm{Zr}_{2}{ }^{+},{ }^{90} \mathrm{Zr}^{+},{ }^{40} \mathrm{Ar}^{63} \mathrm{Cu}^{+}$と干渉するた め, これらの元素は内標準元素として不適当である. In は分子イオン等に干渉されないので, Inについて, Zr の マトリックス効果を検討した。 その結果を Fig. 2 に併せ て示す. Fig. 2 から分かるように，Inの Zrによるマトリ ックス効果は Hf を除く分析元素のそれに極めて近かっ た。それゆえ Inは Hfを除く分析元素について, 内標準 元素として適していることが分かった.

\section{$3 \cdot 5$ 定量分析}

In を内標準元素として, Hf 除くジルコニア中不純物 の定量を行った. 各分析元素について, 濃度とイオンピー ク強度の間に直線関係が成立した $\left(0 \sim 10 \mu \mathrm{g} \mathrm{l}^{-1}\right)$.

$2 \cdot 2$ に従って実試料の分解処理を行うと, 測定溶液中の 試料不純物元素濃度は $1 / 5000$ に希釈される。 そこで, 測 定溶液中の検出限界を求め, 次いでこれらの值を 5000 倍 してジルコニア試料中検出限界を算出した。 検出限界の定 義は 1 回 1 秒間の測定を 10 回積算したものを測定し, こ れを 5 回繰り返したときのバックグラウンドの標準偏差

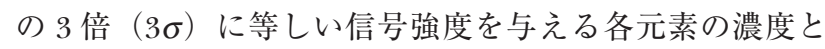
した. 各分析元素についての検出限界を Table 2 に示す. HR-ICP-MS によって得られた検出限界はほとんどの元素 に扔いて $1 \mu \mathrm{g} \mathrm{g}^{-1}$ 以下であり, ICP-AES によって得られた 検出限界の 1 けたから 2 けた良好な值であった ${ }^{1)}$. 特に, 質量数 100 以上の元素については良好な值であった.

Table 2 には空試験結果も示した。空試験值は $\mathrm{Fe}$ と $\mathrm{Pb}$ 以外の測定元素は検出限界以下であった．Fe は干渉する $\mathrm{ArO}$ のすそ野の影響と，溶液中に混入した Feによって空 試験值は検出限界值以上となったと考えられる，Pbは空 試験溶液でも微小ピークが出現するために, 検出限界值以 上という結果になった。しかしながら検出限界值からいっ て, 空試験值は微少量であると言ってよい。したがって, 試料取り扱い時における污染は無視できると考えられる.

HR-ICP-MS を用いて, 市販の 3 種類の高純度ジルコニ アについて，内標準法により得た不純物定量結果を Table 4 に示す。それぞれの結果は，5個ずつの試料を測定した 值の平均値と標準偏差である. 比較のため行った標準添加 法による分析値を括弧内に示した. $\mathrm{Na}, \mathrm{Mg}, \mathrm{Al}, \mathrm{V}, \mathrm{Cr}$, $\mathrm{Ni}, \mathrm{Sr}, \mathrm{Pb}, \mathrm{Bi}$ については双方の結果は良好に一致して いる. La, Ce, Csは，いずれも検出限界值付近であり， この程度の差はやむを得ない、マトリックス効果の結果 で, In と測定元素が近い挙動を示したが, 全く一致した わけではないので，それが誤差になっていると考えられ る. $\mathrm{Ca}, \mathrm{Ti}, \mathrm{Mn}, \mathrm{Fe}$ は検出限界以下であった，Hfにつ いては標準添加法で定量した. Hf について確認のため ICP-AES で得た結果は, HR-ICP-MS で得た結果に近い值 が得られた。 


\section{文献}

1) 石塚紀夫, 上㝨義則, 柘植 明: 分析化学 (Bunseki Kagaku), 34, 487 (1985).

2) R. Lobinski, W. V. Borm, J. A. C. Broekaert, P. Tschöpel, G. Tölg: Fresenius J. Anal. Chem., 342, 563 (1992).

3) R. Lobinski, J. A. C. Broekaert, P. Tschöpel, G. Tölg: Fresenius J. Anal. Chem., 342, 569 (1992).

4) J. A. C. Brokaert, R. Brandt, F. Leis, C. Pilger, D. Pollmann, P. Tschöpel, G. Tölg: J. Anal. At. Spectrom., 9, 1063 (1994).

5) R. S. Houk, V. A. Fassel, G. D. Flesch, H. J. Svec, A. L. Gray, C. E. Taylor: Anal. Chem., 52, 2283 (1980).

6) E. H. Evans, L. Ebdon: J. Anal. At. Spectrom., 5, 425 (1990).

7) D. Beauchemin, J. M. Craig: Spectrochim. Acta, 46B, 603 (1991).

8) M. Morita, H. Ito, T. Uehiro, K. Otsuka: Anal. Sci., 5, 609 (1989).

9) N. Bradshaw, E. F. H. Hall, N. E. Sanderson: J. Anal. At. Spectrom., 4, 801 (1989).

10) I. Feldmann, W. Tittes, N. Jakubowski, D. Stuewer, U. Giessmann: J. Anal. At. Spectrom., 9, 1007 (1994).

11) 望月 正: “プラズマイオン源質量分析”, 河口広司,
中原武利編, p. 88 (1994), (学会出版センター).

12) J. A. Olivares, R. S. Houk: Anal. Chem., 58, 20 (1986).

13) H. Kawaguchi, T. Tanaka, T. Nakamura, M. Morishita, A. Mizuike: Anal. Sci., 3, 305 (1987).

14) D. C. Gregoire: Spectrochim. Acta, 42B, 895 (1987).

15) G. R. Gillson, D. J. Douglas, J. E. Fulford, K. W. Halligan, S. D. Tanner: Anal. Chem., 60, 1472 (1988).

16) B. S. Ross, G. M. Hieftje: Spectrochim. Acta, 46B, 1263 (1991).

17) F. Vanhaecke, H. Vanhoe, R. Dams, C. Vandecasteele: Talanta, 39, 737 (1992).

18) L. Moens, F. Vanhaecke, J. Riondato, R. Dams: J. Anal. At. Spectrom., 10, 569 (1995).

19) D. Merten, J. A. C. Broekaert, R. Brandt, N. Jakubowski: J. Anal. At. Spectrom., 14, 1093 (1999).

20) F. Kohl, N. Jakubowski, R. Brandt, C. Pilger, J. A. C. Broekaert: Fresenius J. Anal. Chem., 359, 317 (1997).

21) J. S. Becker, H. J. Dietze: J. Anal. At. Spectrom., 13, 1057 (1998).

22) M. A. Vaughan, G. Horlick, S. H. Tan: J. Anal. At. Spectrom., 2, 765 (1987).

23) 森田昌敏: “プラズマイオン源質量分析”, 河口広司, 中原武利編, p. 79 (1994), (学会出版センター).

24) 岡本研作：“プラズマイオン源質量分析”, 河口広司, 中原武利編, p. 135 (1994), (学会出版センター).

\section{要 旨}

高分解能誘導結合プラズマ質量分析法により高純度ジルコニア粉末中微量不純物を定量した。ジルコニア 試料 $0.5 \mathrm{~g}$ をテフロン容器中で硫酸 $(1+1) 5 \mathrm{ml}$ により $230^{\circ} \mathrm{C} 40$ 時間加熱して分解した. 高分解能で測定 することにより，ほとんどのスペクトル干渉を回避することができた，Zr によるマトリックス効果につい て検討した．内標準元素として In について検討したところ，Inの Zr によるマトリックス効果は，Hf 除 く分析元素で似ていたため，Hfの定量分析については標準添加法を，それ以外の元素については内標準法 を用いた．Hf は内標準法で求めた定量值と標準添加法で求めたそれとは大きく違ったが，それ以外の元素 は極めて近い值が得られた。標準添加法で得た Hf 濃度は, 誘導結合プラズマ原子発光分析法で得られた值 に極めて近い值となった．各不純物元素の固体試料中の検出限界は 0.01 から $9 \mu \mathrm{g} \mathrm{g}^{-1}$ であった. 市販され ている 3 種類の高純度ジルコニア粉末中 $\mathrm{Na}, \mathrm{Mg}, \mathrm{Al}, \mathrm{Ca}, \mathrm{Ti}, \mathrm{V}, \mathrm{Cr}, \mathrm{Mn}, \mathrm{Fe}, \mathrm{Ni}, \mathrm{Sr}, \mathrm{Cs}, \mathrm{La}, \mathrm{Ce}$, $\mathrm{Hf}, \mathrm{Pb}, \mathrm{Bi}$ の 17 元素の定量を行った. 